\title{
Examination of Stomach Contents in Xanthid Crabs
}

\author{
Toshio SaIsho, ${ }^{* 1}$ Tamao Noguchi, ${ }^{* 2}$ Kinue Koyama, ${ }^{* 2}$ Atsushi UzU, ${ }^{* 2}$ \\ Toshitaka KIKUTA, ${ }^{* 1}$ and Kanehisa HASHIMOTO*2 \\ (Received September 29, 1982)
}

\begin{abstract}
In order to elucidate the infestation mechanism of toxic crabs with paralytic shellish poison (PSP), three xanthid crabs (Zosimus aeneus, Atergatis floridus and Platypodia granulosa) collected from Ishigaki Island and Miura Peninsula, were surveyed for stomach contents. Stomach contents of the three toxic crabs from Ishigaki Island consisted of red algae, animal tissues, corals, sand, etc., irrespective of their PSP toxicity levels. The same stomach contents composition was encountered in a nontoxic crab Daira perlata examined for comparison. Stomach contents of $A$. floridus specimens collected from Miura Peninsula showed a somewhat different composition, in which Hypnea sp., bivalves, gastropods, animal tissues and sand were dominant.

No definite conclusion was drawn from these data, as to the association of the eating habit of these toxic crabs with their PSP toxification.
\end{abstract}

Three xanthid crabs, Zosimus aeneus, Atergatis floridus, and Platypodia granulosa, which inhabit the Ryukyu and Amami Islands, are known to be highly infested with paralytic shellfish poison (PSP). ${ }^{1)}$ In the previous paper, ${ }^{23}$ we reported that $A$. floridus possesses a much stronger PSP and tetrodotoxin resistibility than nontoxic crabs. This, together with that the eggs of $A$. floridus were toxic, and that the toxicity level hardly changed during a long feeding period with nontoxic diet, ${ }^{* 9}$ suggests that the PSP involved in toxic crabs is endogenous.

On the other hand, the individual and local variations of toxicity in those crabs, seem to support that the toxin is rather exogenous.*3

The present study was undertaken to elucidate the PSP infestation mechanism. This paper deals with the eating habits of the above xanthid crabs, as examined from the composition of their stomach contents.

\section{Materials and Methods}

Toxic Crabs

Thirty-seven $Z$. aeneus specimens, twentyeight $A$. floridus specimens, and two $P$. granulosa specimens, were collected from Ishigaki Island,
Okinawa Prefecture, in 1979-1981. The specimens were immediately frozen, transported to the Laboratory of Marine Biochemistry, the University of Tokyo, and kept frozen until used. Besides, 75 specimens of $A$. floridus were collected from some localities of Miura Peninsula, Kanagawa Prefecture, and kept frozen similarly. The details of all these crab specimens are shown in Tables 1-5.

The specimens were examined for PSP toxicity and subsequently for stomach contents, as described below.

\section{Nontoxic Crab}

Twenty specimens of Daira perlata were collected from Ishigaki Island, and similarly examined after transportation to the University of Tokyo.

\section{Assay of Toxicity}

A leg or legs were torn off from each crab specimen and determined for PSP toxicity by the usual method. ${ }^{3)}$

\section{Examination of Stomach Contents}

The contents were squeezed out from the stomach of each crab specimen, weighed, and examined microscopically.

*1 Laboratory of Zoology, Faculty of Fisheries, Kagoshima University, Shimoarata, Kagoshima 890, Japan (税所俊郎・料田敏孝: 黁児岛大学水産学部)。

*2 Laboratory of Marine Biochemistry, Faculty of Agriculture, University of Tokyo, Bunkyo, Tokyo 113, Japan (野口玉雄・小山綟江・宇津 敦・橋本周久：東京大学農学部).

*8 T. Noguchi, K. Koyama, A. Uzu, and K. Hashrmoto: The Abstracts of Oral Presentation of the Spring Meeting of Japan. Soc. Sci. Fish., p. 269 (1982). 


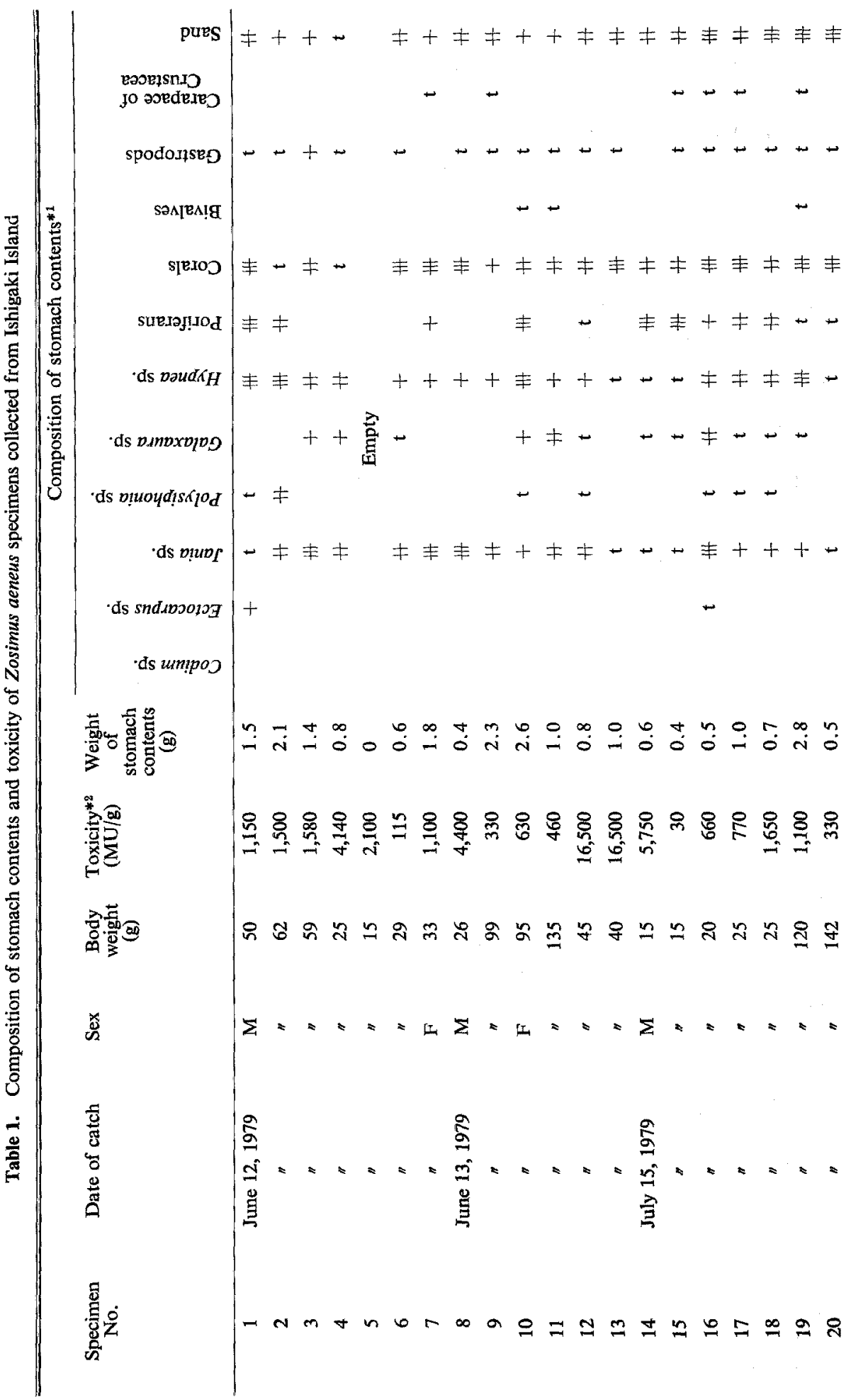




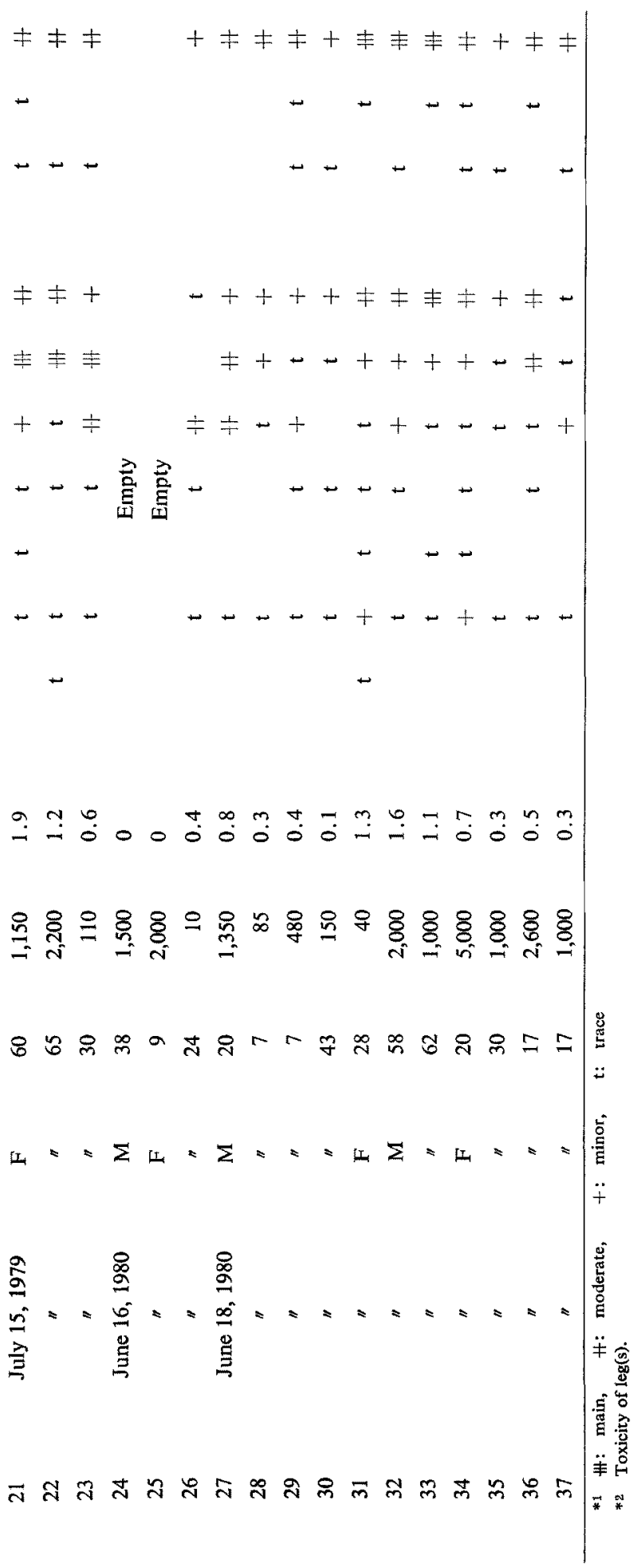




\section{Results and Discussion}

\section{Stomach Contents in Zosimus aeneus}

The composition of stomach contents in the $Z$. aeneus specimens are shown in Table 1 , together with their toxicity scores.

The contents consisted of a green alga (Codium sp.), a brown alga (Ectocarpus sp.), red algae (Jania sp., Polysiphonia sp., Galaxaura sp., and Hypnea sp.), poriferans, corals, bivalves, gastropods, and sand. As shown in Table 1, Jania sp., Hypnea sp., corals and sand were dominant in stomach contents of all the specimens collected in June, 1979. In several specimens, poriferans were also dominant. In the specimens collected in July 1979 and June 1980, corals, sand, poriferans and Hypnea sp. were dominant, followed by Jania sp. The composition of stomach contents of these three lots of different collection dates were, however, roughly comparable to each other.

SAISHO and USHIO ${ }^{4}$ examined stomach contents in six toxic $Z$. aeneus specimens caught at Amami Is. in June to November 1967, and found the debris of various species of algae: Codium sp., Chlorodesnis comosa, Ectocarpus sp., Sphacelaria sp., Jania sp., Hypnea sp. and Polysiphonia sp. Poriferans and corals were also detected.

The $Z$. aeneus specimens collected from Ishigaki Is. this time were very similar to the Amami specimens in stomach contents composition except that a brown alga Sphacelaria sp. was present in the latter. ${ }^{4}$ ) The toxicity levels of the $Z$. aeneus specimens ranged from 10 to $16,500 \mathrm{MU} / \mathrm{g}$. However, no clear relationship was observed between the toxicity value and the composition of stomach contents.

From the above results, $Z$. aeneus is postulated to be rather omnivorous than hervivorous, since parts of animal tissues, though not so much, were always found in the stomach.

\section{Stomach Contents in Atergatis floridus}

The results with $A$. floridus are summarized in Tables 2 (Ishigaki Is.) and 3 (Miura Peninsula).

Some local variations of the composition of stomach contents were recognized between the Ishigaki and Miura specimens.

Ishigaki specimens; In the specimens collected in June 1979, Hypnea sp., sand, shells, animal tissues, poriferans and fish fragments were detected. No parts of Jania sp., Polysiphonia sp., Galaxaura sp., were found. The toxicity scores of the crab specimens ranged from 78 to 3,600 $\mathrm{MU} / \mathrm{g}$. In the specimens collected in June 1980, Codium sp., Ectocarpus sp., Jania sp., Galaxaura sp., Hynea sp., annelids, animal tissues, corals and sand were identified or confirmed. The toxicity scores of the A. floridus specimens ranged from 10 to $100 \mathrm{MU} / \mathrm{g}$. The composition of stomach contents is more similar to that of the $Z$. aeneus specimens collected in 1979 to 1980 , than that of the A. floridus specimens collected in June 1979.

Jania sp., Polysiphonia sp., Galaxaura sp., Hypnea sp., poriferans, corals, bivalves, gastropods, animal tissues, shells and sand appeared in the specimens collected through April to July, 1981. Hypnea sp., animal tissues, corals and sand were found in most of the specimens. This composition is similar to that of the specimens collected in June 1980. Toxicity values were fairly high, ranging from 200 to $9,000 \mathrm{MU} / \mathrm{g}$.

Miura specimens: The stomachs of the specimens collected at Enoshima in November 1981, contained Hypnea sp., bivalves, gastropods, animals tissues and sand. Sand was common in all the specimens. The toxicity value was 80 $\mathrm{MU} / \mathrm{g}$ on the average. In the specimens collected at Arazaki through May to September 1981, Hypnea sp., red algae, poriferans, bivalves, animal tissues and sand were identified. The toxicity values ranged from 10 to $300 \mathrm{MU} / \mathrm{g}$. As described above, the stomachs of the A. floridus specimens from Miura Peninsula contained animal tissues abundantly, followed by algae. No coral pieces were detected.

\section{Stomach Contents in Platypodia granulosa}

The results with two $P$. granulosa specimens collected in July 1981, are summarized in Table 4.

Poriferans and corals were dominant, while Hypnea sp., other red algae, bivalves and nemerteans were minor. Their toxicity values were 1,000 and $3,000 \mathrm{MU} / \mathrm{g}$.

The composition of stomach contents is similar to that of the $A$. floridus specimens collected from Miura Peninsula.

\section{Stomach Contents in Daira perlata}

The results with twenty $D$. perlata specimens collected from Ishigaki Is. are summarized in Table 5. No toxicity was detected in any of them. Main stomach contents were Jania sp., Hypnea sp., Ectocarpus sp. and corals, while Codium sp., Caulerpa sp., other brown algae, Galaxaura sp., Gelidium sp., other crustacea, and sand were also 
Examination of stomach contents in xanthid crabs

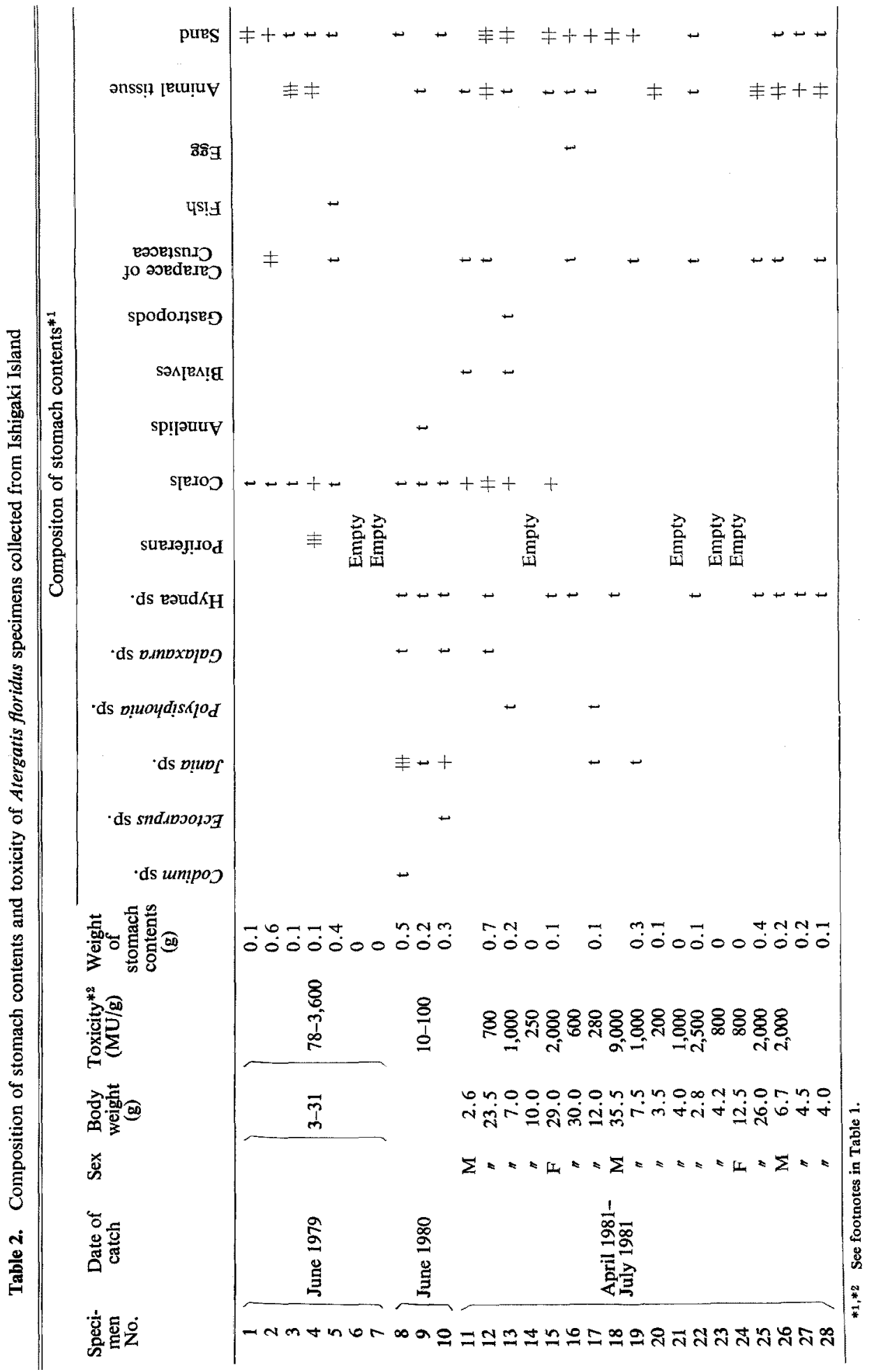


Saisho, Noguchi, Koyama, Uzu, KikUta, and Hashimoto

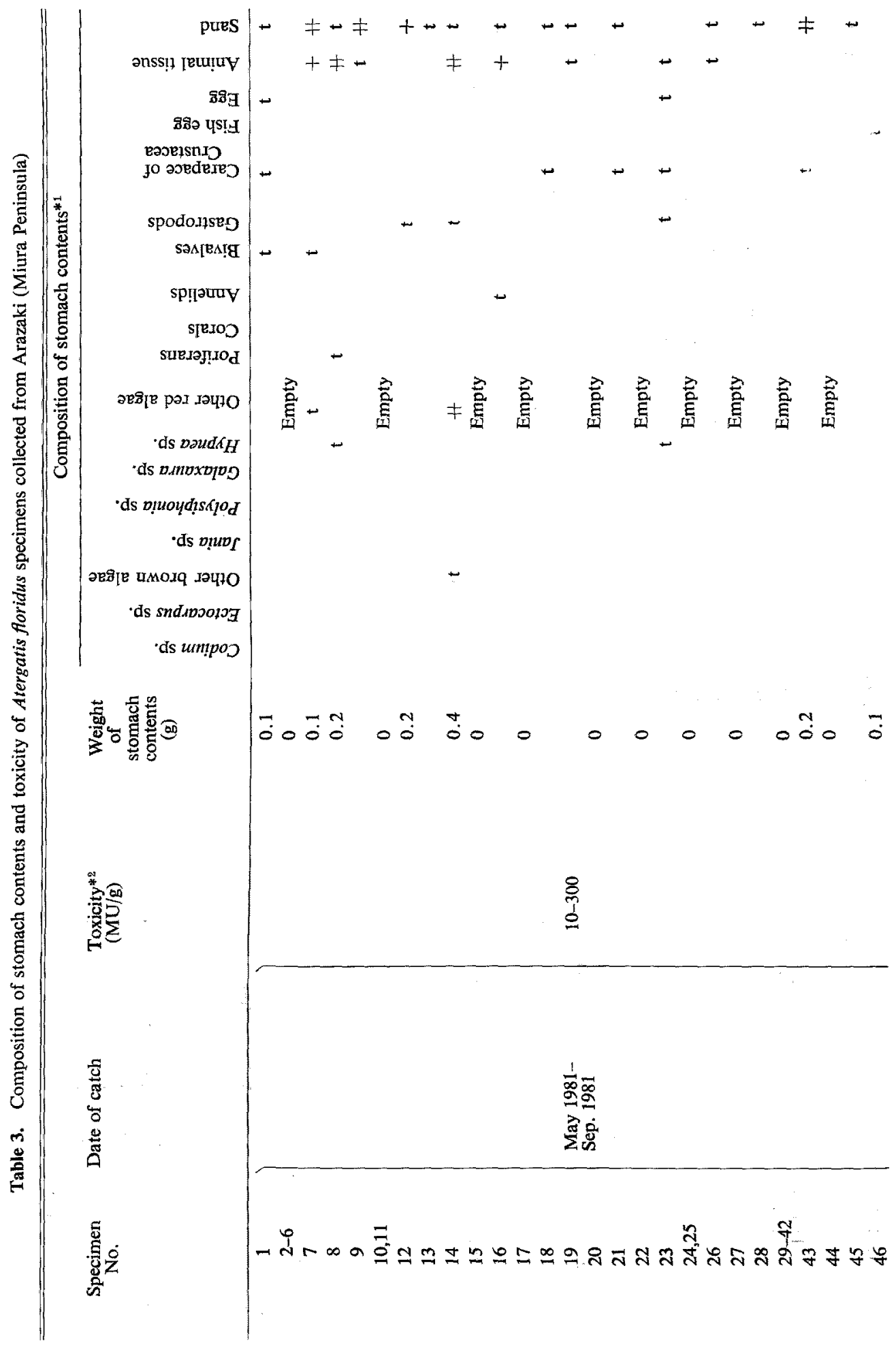


Examination of stomach contents in xanthid crabs

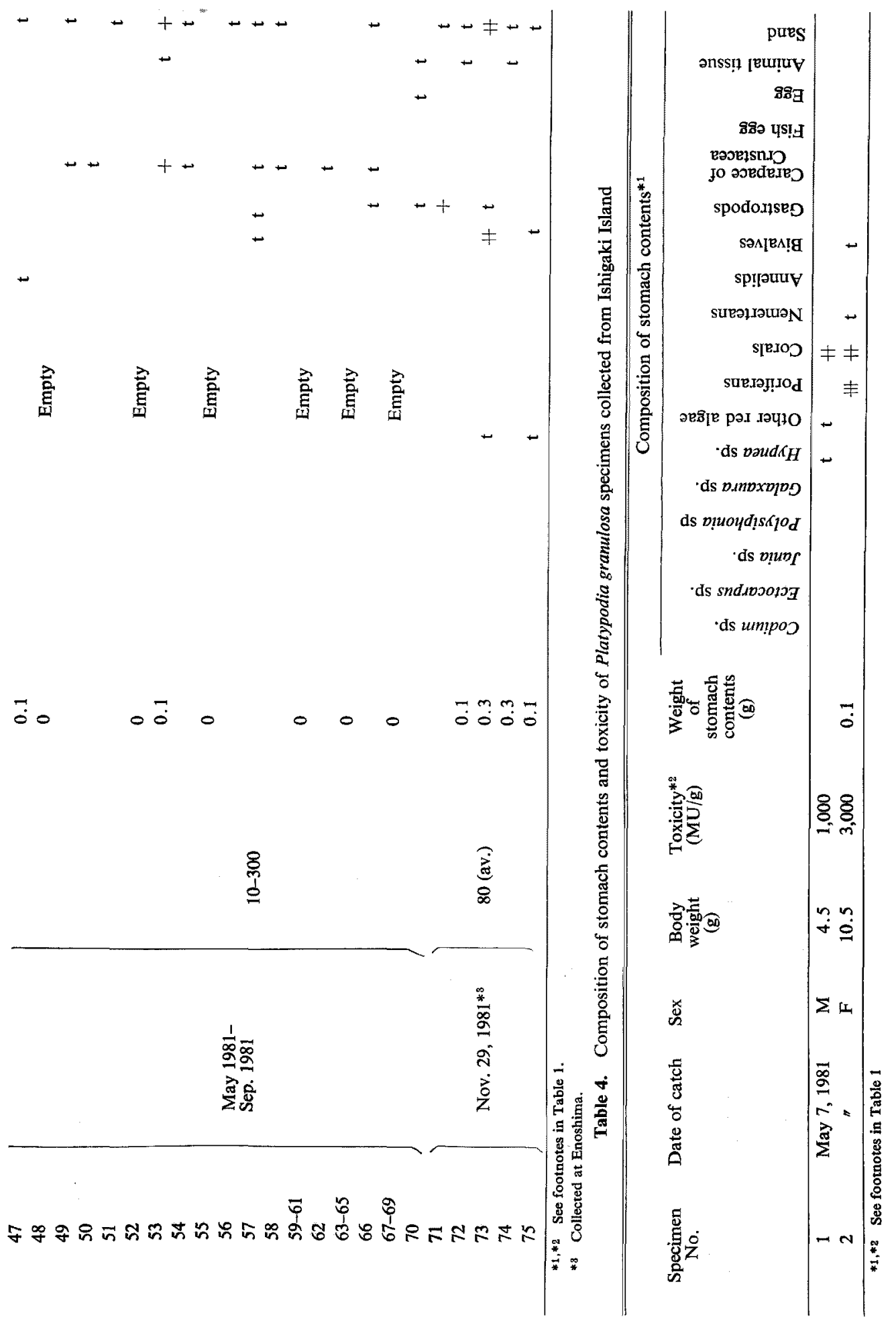




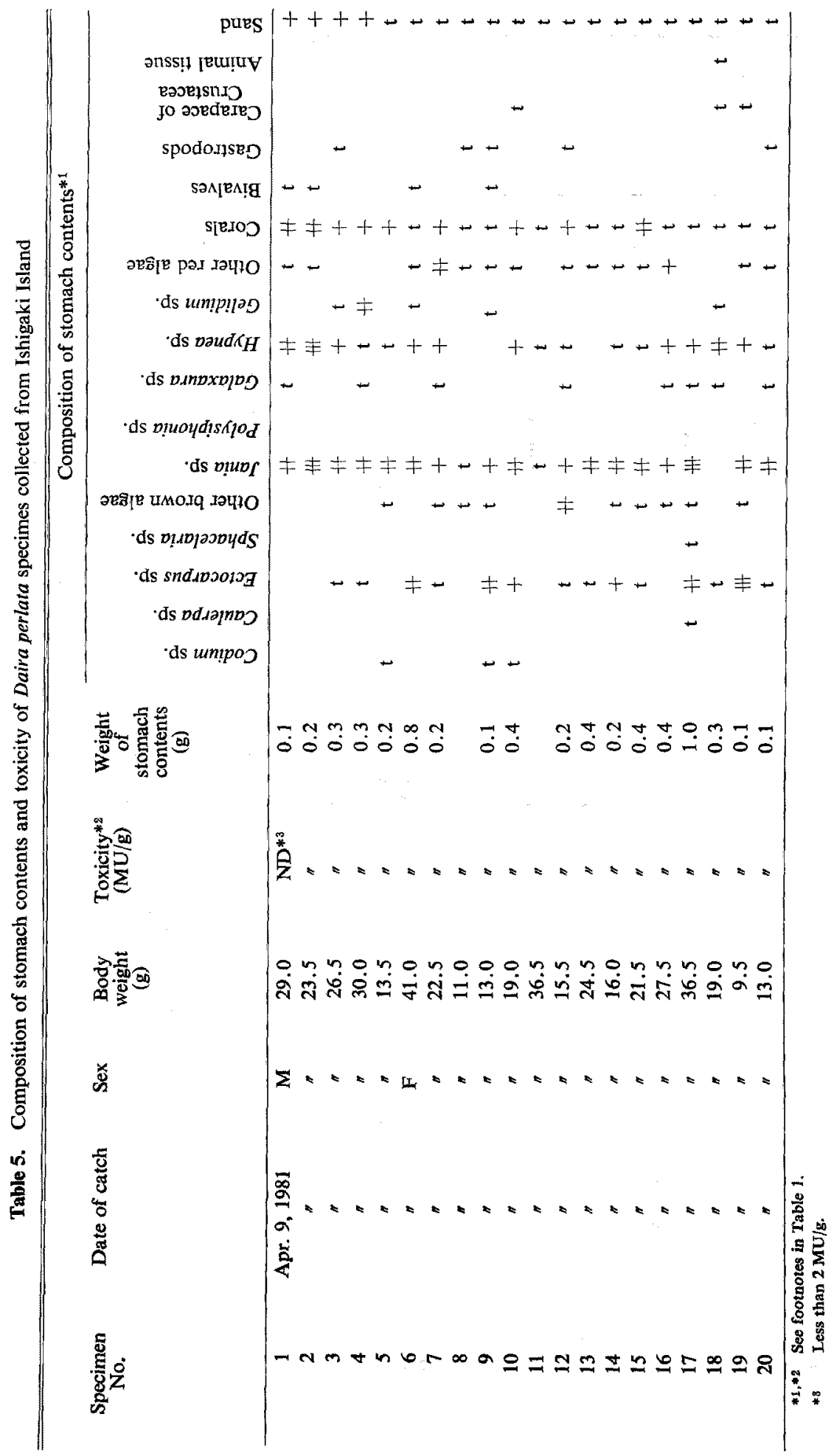


detected.

This composition agrees well with that of the $Z$. aeneus specimens which were collected from Ishigaki Is. through 1979 to 1980 and showed high toxicity values as described above.

The stomach contents in $Z$. aeneus, A. floridus and $D$. perlata, all collected at Ishigaki Is., were very similar to each other. They inhabit coral reefs and are likely to have the same eating habits. However, the specimens of $Z$. aeneus and $A$. floridus generally showed high toxicity values while those of $D$. perlata no toxicity. On the other hand, $\boldsymbol{P}$. granulosa at Ishigaki Is., also inhabit coral reefs and the two specimens examined here showed high toxicity values, though their stomach contents composition differed from those of the above species. It rather resembles that of A. floridus specimens collected from Miura Peninsula, although the $P$. granulosa specimens and the $A$. floridus specimens from Miura Peninsula were significantly different from each other as far as the toxicity scores are concerned (Tables 3 and 4). As common stomach contents of $Z$. aeneus and $A$. floridus collected from Ishigaki Is., Jania sp., Polysiphonia sp., Galaxaura sp., Hypnea sp., poriferans, corals, bivalves, gastropods, carapace of crustacea and sand were listed up. When the results with $P$. granulosa are also taken in, Hypnea sp., poriferans, bivalves, carapace of crustacea, and sand are listed up as common stomach contents. However, those were also almost common to the $D$. perlata specimens which did not show any toxicity.

Thus, the origin of PSP in those toxic crabs has not been found in their stomach contents. As reported before, ${ }^{2)}$ toxic crab species possess an extremely strong PSP resistibility in comparison with nontoxic crabs. Considering also that the eggs of $A$. floridus were toxic, and that toxic crabs maintained a fairly high toxicity level for a long period when fed nontoxic diets, PSP in toxic crabs may be endogenous, some portion being inherited from their parents and the rest being synthesized in vivo. On the other hand, wide individual and local variations of toxicity value were observed in the same species (Table 1-4), suggesting that PSP in toxic crabs is related to some environmental factor(s), or that it comes from a food. Even in this case, the mechanism may not be a simple food chain. Toxicity assay of the foods to be ingested by toxic crabs, and of the crabs fed the diets of above compositions will be needed to elucidate the PSP-infestation mechanism in those toxic crabs.

\section{Acknowledgements}

The authors express sincere thanks to Director A. Tomorı and Mr. M. Murakoshi, Yaeyama Branch of the Okinawa Fisheries Experimental Station, for their kind collaboration in collecting the crab specimens.

\section{References}

1) K. Koyama, T. Nogucht, Y. UeDA, and K. Hashimoto: Bull. Japan. Soc. Sci. Fish., 47, 965 (1981).

2) K. Koyama, T. Noguchi; A. Uzu, and $K$. HASHIMOTO: Bull. Japan. Soc. Sci. Fish., 49, 485489 (1983).

3) Environmental Health Bureau, Ministry of Health and Welfare (ed.); Shokuhin Eisei Kensa Shishin (Shokuhinbetsu), Nippon Shokuhin Eisei Kyokai, Tokyo, 1978, pp. 240-244.

4) T. SAisho and Y. Ushio: Mem. Fac. Fish., Kagoshima Univ., 18, 47-63 (1969). 